\title{
The Effectiveness of Photocatalytic Ionisation Disinfection of Filter Materials
}

\author{
KATARZYNA PIETRZAK ${ }^{1 \star}$ and BEATA GUTAROWSKA ${ }^{1}$ \\ ${ }^{1}$ Institute of Fermentation Technology and Microbiology, Łódź University of Technology, Poland
}

Received 31 August 2012, revised 19 January 2013, accepted 12 March 2013

\begin{abstract}
The purpose of this study was to determine the effectiveness of photocatalytic ionisation as a disinfection method for filter materials contaminated by microorganisms, and to assess how air relative humidity $(\mathrm{RH})$, time and microbe type influence the effectiveness of this disinfection. In the quantitative analysis of a used car air filter, bacterial contamination equalled $1.2 \times 10^{5} \mathrm{cfu} / \mathrm{cm}^{2}$, fungal contamination was $3.8 \times 10^{6} \mathrm{cfu} / \mathrm{cm}^{2}$, and the isolated microorganisms were Aspergillus niger, Bacillus megaterium, Cladosporium herbarum, Cryptococcus laurenti, Micrococcus sp., Rhodotorula glutinis and Staphylococcus cohnii. In the model experiment, three isolates (C. herbarum, R. glutinis, S. cohnii) and 3 ATCC species (A. niger, E. coli, S. aureus) were used for photocatalytic ionisation disinfection. The conditions of effective photocatalytic ionisation disinfection ( $\mathrm{R} \geq 99.9 \%$ ) were established as $2-3 \mathrm{~h}$ at $\mathrm{RH}=77 \%$ (bacteria) and $6-24 \mathrm{~h}$ at $\mathrm{RH}=53 \%$ (fungi). $\mathrm{RH}$ has an influence on the effectiveness of the photocatalytic disinfection process; the highest effectiveness was obtained for bacteria at $\mathrm{RH}=77 \%$, with results $5 \%$ higher than for $\mathrm{RH}=49 \%$. The studies show that the sensitivity of microorganisms to photocatalytic ionisation disinfection is ordered as follows: Gram-positive bacteria (S. cohnii, S. aureus), Gram-negative bacteria (E. coli), yeasts (R. glutinis), and moulds (C. herbarum, A. niger). Of all the mathematical models used for the description of death dynamics after photocatalytic ionisation disinfection, the Chick-Watson model is the most useful, but for more resistant microorganisms, the delayed Chick-Watson model is highly recommended. It therefore seems, that the presented disinfection method of photocatalytic ionisation can be successfully used to clean filtration materials.
\end{abstract}

Key words: disinfection, filter materials, microorganisms, photocatalytic ionisation

\section{Introduction}

The photocatalytic characteristics of titanium dioxide $\left(\mathrm{TiO}_{2}\right)$ were discovered in 1967 by (Fujishima and Honda, 1972). This process was called the HondaFujishima effect. During the process, on a solid semiconductor catalyst, Reactive Oxygen Species (ROS) such as $\mathrm{OH}^{-}, \mathrm{O}_{2}^{-}$and also $\mathrm{H}_{2} \mathrm{O}_{2}, \mathrm{OH}^{-}, \mathrm{H}^{+}$are generated when exposed to light of the appropriate wavelength.

Reactions on the semiconductor valence band (Chen et al., 2010):

$$
\begin{aligned}
& \mathrm{TiO}_{2}\left(\mathrm{~h}^{+}\right)+\mathrm{H}_{2} \mathrm{O} \rightarrow \mathrm{TiO}_{2}+\mathrm{OH}^{\cdot}+\mathrm{H}^{+} \\
& \mathrm{TiO}_{2}\left(\mathrm{~h}^{+}\right)+\mathrm{OH}^{-} \rightarrow \mathrm{TiO}_{2}+\mathrm{OH}^{\cdot} \\
& \mathrm{TiO}_{2}\left(2 \mathrm{~h}^{+}\right)+2 \mathrm{H}_{2} \mathrm{O} \rightarrow \mathrm{TiO}_{2}+\mathrm{H}_{2} \mathrm{O}_{2}+2 \mathrm{H}^{+}
\end{aligned}
$$

Reactions on the semiconductor conduction band (Cho et at., 2004a):

$$
\begin{aligned}
& \mathrm{TiO}_{2}\left(\mathrm{e}^{-}\right)+\mathrm{O}_{2} \rightarrow \mathrm{TiO}_{2}+\mathrm{O}_{2}^{-\cdot} \\
& \mathrm{TiO}_{2}\left(\mathrm{e}^{-}\right)+\mathrm{O}_{2}^{-\cdot}+2 \mathrm{H}^{+} \rightarrow \mathrm{TiO}_{2}+\mathrm{H}_{2} \mathrm{O}_{2} \\
& \mathrm{TiO}_{2}\left(\mathrm{e}^{-}\right)+\mathrm{H}_{2} \mathrm{O}_{2} \rightarrow \mathrm{TiO}_{2}+\mathrm{OH}^{\cdot}+\mathrm{OH}^{-} \\
& \mathrm{O}_{2}^{-\cdot}+\mathrm{H}_{2} \mathrm{O}_{2} \rightarrow \mathrm{O}_{2}+\mathrm{OH}^{-}+\mathrm{OH}^{-}
\end{aligned}
$$

The mechanism of action on bacteria is quite well known. Microorganisms consist of $70-90 \%$ water, and the cellular constituents such as polysaccharides, lipids, proteins and nucleic acids can be attacked by ROS and finally lead to cell death. The majority of research indicates destruction of the cell membrane as the main inactivation process (Greist et al., 2002). Peptidoglycan maintains cell rigidity to preserve the shape and internal pressure. The influence of ROS is most crucial in Gram-positive bacteria, in which the layer can account for as much as $90 \%$ of the cell wall. For comparison, in Gram-negative bacteria it makes up only about $10 \%$ of the cell wall ( $\mathrm{Lu}$ et al., 2003). The next ROS targets are lipids and polysaccharides, which apart from contributing to structural integrity, are of crucial importance to Gram-negative bacteria. Lipids are associated with endotoxin activity and polysaccharide immunogenicity (Sunada et al., 1998; Veremeichenko and Zdorovenko, 2004). Also enzymes are common target sites, especially coenzyme A, which takes part in the synthesis and oxidation of fatty acids and the oxidation of pyruvate in the citric acid cycle (Matsunaga et al., 1985; Hidaka et al., 1997). DNA is especially susceptible to oxidative stress. ROS may attack at the sugar or at the base part, causing the formation of a large number of products (Gogniat

* Corresponding author: K. Pietrzak, Institute of Fermentation Technology and Microbiology, Łódź University of Technology, 171/173 Wólczańska St., 90-924 Łódź, Poland; phone: +48 426313 272, fax: +48 426365 976; e-mail: khpietrzak@gmail.com 
and Dukan, 2007; Dalrymple et al., 2010). Research has shown the effectiveness of photocatalytic ionisation on microorganisms, e.g. Bacillus sp., Pseudomonas sp., Staphylococcus sp., Fusarium sp., Candida sp. and viruses (Foster et al., 2010).

Nowadays, photocatalytic ionisation has a wide spectrum of applications. It is used in exterior construction materials in tiles, glass, tents, plastic films, aluminium panels, coatings, in interior furnishing materials like wallpaper, window blinds, also in purification facilities: air cleaners, air conditioners, purification systems for wastewater and sewage, purification systems for pools, and in household goods, like fibres, clothes, leathers, lightings and sprays (Fujishima and Zhang, 2006). However there are no studies concerning the behaviour of microorganisms on technical materials such as textiles, polymers, glass and metal during photocatalytic ionisation disinfection.

The purpose of ventilation and air conditioning is to ensure a suitable quality of air for the indoor environment (buildings, cars). Filters placed in the ventilation ducts stop atmospheric aerosols containing particles of mineral dust, dust from car exhaust fumes or dust from home heating. Apart from inorganic particles, bioaerosols are also stopped; these have a large impact on human health. Microorganisms can easily enter the human respiratory tract, causing serious diseases, bacterial and fungal infections, mycotoxicosis and allergies (Chapman, 2006). The particle diameters are divided into groups: PM1 - respirable dust with a diameter less than 1 micron (reaches alveoli); PM2.5 - respirable dust with a diameter less than 2.5 microns (reaches alveoli); PM4 - respirable dust with a diameter less than 4 microns (reaches trachea and bronchi); PM10 - suspended dust with diameter less than 10 microns (reaches mouth and nose) (Gursumeeran Satsangi et al., 2011). A standard car filter has a pore size equal to $10 \mu \mathrm{m}$, so it always stops particles from the last group. In the air, microorganisms are present most frequently in the form of bioaerosols with diameters above $10 \mu \mathrm{m}$. From the literature, it is known that microorganisms in the air of high relative humidity may develop actively on filter materials using the organic contamination in the form of dust. The number of microorganisms stopped by a cellulose ventilation filter equals $10^{3}-10^{4} \mathrm{cfu} / \mathrm{g}$ cellulose (Szponar, 2010). AC car systems should be disinfected; filter disinfection can inhibit microorganisms' growth (biofilm formation), thus prolong the service life and reduce the risk of secondary microbial contamination. There are many companies offering disinfection of car air conditioning systems using ultrasounds, ozonation and preparations containing quaternary ammonium salts, chlorides, alcohols or nanosilver. Additionally, cleaning methods might remove odours from the environment.
There are no reports in the literature concerning photocatalytic ionisation disinfection of microbiologically contaminated filter materials. However mathematical models of microorganism number reduction are described. It has not been hitherto known whether the mathematical models describing the degradation of microorganisms during disinfection in model studies (Cho et al., 2004b; Chen et al., 2009) will be confirmed in studies when the microorganisms are placed on the filter materials. This gap can be filled with the results presented below.

The purpose of this study was to determine the effectiveness of photocatalytic ionisation as a disinfection method for filter materials contaminated by microorganisms and to assess how air relative humidity, time and microbe type influence the effectiveness of this disinfection. The scope of the research included the isolation and identification of bacteria and fungi from used car filter materials, evaluation of the effectiveness of photocatalytic ionization of three isolates from a car filter and three ATCC test microorganisms under model conditions on filter materials, assessment of the impact of air relative humidity and time on the efficacy of photocatalytic ionisation disinfection, and the mathematical description of the reduction in the number of microorganisms on the filter material.

\section{Experimental}

Materials and Methods

Test filter material. The test object was a car cabin air filter (WA60-115, manufacturer: Label Filter 'PZL Sedziszow S.A.', Poland). The filter was made of cellulose, polyester fibres and binders. Pure filters were used for the following studies, and 3 used ones (in a car for 1 year) were used for isolation of microorganisms. In the model study, the pure filter samples $(2 \times 2 \mathrm{~cm})$ were sterilised by UV light for 1 hour on both sides to remove microorganisms.

Microorganisms. Bacteria and fungi from the American Type Culture Collection were used in the experiment: Staphylococcus aureus (ATCC 6538), Escherichia coli (ATCC 10536), Aspergillus niger (ATCC 16404). ATCC microbes were chosen because they are commonly used as test organisms for the estimation of disinfection effectiveness. Moreover, one bacterium and two fungi which were isolated with the highest isolation frequency (> 80\%) from the used cabin car filters were also used: Staphylococcus cohnii, Cladosporium herbarum and Rhodotorula glutinis.

Microorganism isolation. The 3 samples from each of 3 used car filters were introduced into saline $(0.85 \%$ $\mathrm{NaCl}$ ) and the method of serial dilutions was done. For 
bacteria isolation, TSA medium (Tryptic Soy Broth, Merck, Germany) was used, while fungi were isolated using MEA medium (Malt Extract Agar, Merck, Germany). The samples were incubated for $24-48 \mathrm{~h}$ at $30^{\circ} \mathrm{C}$ for bacteria and $3-5$ days at $27^{\circ} \mathrm{C}$ for fungi. Next, the quantity of microbiological contamination of the material was estimated and expressed in $\mathrm{cfu} / \mathrm{cm}^{2}$, then pure cultures of the strains were obtained.

Identification of microorganisms. The diagnostics of bacteria were based on the observation of macroscopic features, Gram staining, catalase and cytochrome oxidase test (Microbiologie Bactident Oxydase, Merck, Germany). The identification was performed using API $\mathrm{CH}$, API STAPH tests (bioMérieux, France). Identification of moulds was performed by comparison of macro- and microscopic observations on media: MEA, CYA (Czapek Yeast Agar, Merck, Germany) and YES (Yeast Extract with Supplements, Germany, Merck) with taxonomic keys (Samson et al., 1996; Flannigan et al., 2001). Yeasts were identified using the API C AUX test (bioMérieux, France).

Inoculum preparation. The bacteria colonies from TSA medium agar slants $\left(24 \mathrm{~h}, 30^{\circ} \mathrm{C}\right)$ were transferred into $10 \mathrm{ml}$ of liquid TSB medium (Tryptic Soy Broth, Merck, Germany) and incubated for $24 \mathrm{~h}$ at $30^{\circ} \mathrm{C}$. The yeasts and moulds were incubated for 5 days at $27^{\circ} \mathrm{C}$ on MEA medium agar slants and then washed using $10 \mathrm{ml}$ of MEB medium (Malt Extract Broth, Merck, Germany). The densities of inoculums were established. The bacterial inoculum densities obtained were approximately $5 \times 10^{7} \mathrm{cfu} / \mathrm{ml}, 2 \times 10^{8} \mathrm{cfu} / \mathrm{ml}, 7 \times 10^{9} \mathrm{cfu} / \mathrm{ml}$ for S. cohnii, S. aureus, E. coli respectively. The fungal inoculum densities were approximately $3 \times 10^{7} \mathrm{cfu} / \mathrm{ml}$ for A. niger, C. herbarum and $5 \times 10^{8} \mathrm{cfu} / \mathrm{ml}$ for R. glutinis.

\section{Photocatalytic ionisation disinfection process}

Photocatalytic ionisation device. The tested photocatalytic ionisation unit $\left(c a .0 .3 \mathrm{~m}^{3}\right)$ consists of a ventilation chamber, $12 \mathrm{~V}$ DC transformer, UV lamp $(254 \mathrm{~nm}), \mathrm{TiO}_{2}$-coated tubes with additives (commercially available) and a mounting rack. The device was designed for experimental purposes.

Disinfection. The disinfection was carried out for six microorganisms. The inoculum of each microorganism $(0.1 \mathrm{ml})$ was transferred onto the aseptic filter sample. Then the filters were placed in the photocatalytic unit. Samples were removed from the device after $0,5,15,30,45,60,120,180$ minutes for bacteria and after $0,2,4,6,8,12$ hours for fungi. The disinfection time was dependent on the expected sensitivity and established according to literature model studies on the same strains. In these time intervals, air relative humidity and temperature were measured. The experiment was performed under three variants of average air relative humidity conditions: $\mathrm{RH}=49 \%, \mathrm{RH}=53 \%$ and
$\mathrm{RH}=77 \%$. These $\mathrm{RH}$ s were chosen due to the prevailing conditions in car spaces without AC $(\mathrm{RH}=40-50 \%)$ and with $\mathrm{AC}(\mathrm{RH}>70 \%)$. The air relative humidity and temperature were measured using a portable hygrometer (PWT-401, Elmetron, Poland). All samples were measured in triplicate.

The collected filter was transferred into saline $(0.85 \% \mathrm{NaCl})$, then the method of serial dilutions in saline and the culture method were performed. Bacteria were incubated $24-48 \mathrm{~h}$ at $30^{\circ} \mathrm{C}$, and fungi for $3-5$ days at $27^{\circ} \mathrm{C}$. After incubation the colonies were counted, and the result was given in colony forming unit per $1 \mathrm{ml}(\mathrm{cfu} / \mathrm{ml})$.

Additionally, a control process (with photocatalytic ionisation device turned off) was conducted for all tested species under the same conditions.

Mathematical calculations. The isolation frequency for all microorganisms isolated from the filter, the arithmetic mean and the standard deviation for the number of microorganisms after and before disinfection were calculated. The reduction in the number of microorganisms after disinfection $\mathrm{R}(\%)$ was determined using the formula:

$$
\mathrm{R}=\left[\left(\mathrm{n}_{0}-\mathrm{n}_{\mathrm{t}}\right) / \mathrm{n}_{0}\right] \times 100 \%
$$

where:

$\mathrm{n}_{0}=$ number of microorganisms at time $\mathrm{t}=0 \mathrm{~h}$ before the disinfection (cfu/sample);

$\mathrm{n}_{\mathrm{t}}=$ number of microorganisms after disinfection time $\mathrm{t}_{\mathrm{n}}$ (cfu/sample).

The number of microorganisms reduced during the one hour of photocatalytic ionisation disinfection $\mu_{1}(\mathrm{cfu} / \mathrm{h})$ was described by the linear mathematical function:

$$
\mathrm{C}_{0}=\mu_{1} \times \mathrm{t}+\mathrm{b}
$$

where:

$\mathrm{C}_{0}=$ number of microorganisms before the disinfection process (cfu/sample);

$\mu_{1}=$ reduction rate calculated from the linear function (cfu/h);

$\mathrm{t}=$ disinfection time $(\mathrm{h})$;

$\mathrm{b}=$ the function parameter.

The rate of microorganism reduction $\mu_{2}(1 / \mathrm{h})$ during the photocatalytic ionisation disinfection was also calculated using the Chick-Watson model (Chen et al., 2009):

$\log \left(\mathrm{C} / \mathrm{C}_{0}\right)=\mu_{2} \times \mathrm{t}$

$\mathrm{C}=$ number of microorganisms after the disinfection process (cfu/sample);

$\mathrm{C}_{0}=$ number of microorganisms before the disinfection process (cfu/sample);

$\mu_{2}=$ reduction rate calculated with the Chick-Watson model $(1 / \mathrm{h})$;

$\mathrm{t}=$ disinfection time $(\mathrm{h})$ 
$\mu_{2}=-\mathrm{k}$ (acc. to Chen et al., 2009,

where $\left.\log \left(\mathrm{C} / \mathrm{C}_{0}\right)=-\mathrm{k} \times \mathrm{t}\right)$

The rate of microorganism reduction $\mu_{3}(1 / \mathrm{h})$ during the photocatalytic ionisation disinfection was calculated using the delayed Chick-Watson model, which includes shoulder region of the death dynamics apart from the log-linear region (Cho et al., 2004b):

$$
\begin{aligned}
& \log \left(\mathrm{C} / \mathrm{C}_{0}\right)=\left\{0 \text { for } \mathrm{t} \leq \mathrm{t}_{\mathrm{s}}\right. \\
& \mu_{2} \times\left(\mathrm{t}-\mathrm{t}_{\mathrm{s}}\right) \text { for } \mathrm{t}>\mathrm{t}_{\mathrm{s}}
\end{aligned}
$$

where:

$\mathrm{C}=$ number of microorganisms after the disinfection process (cfu/sample);

$\mathrm{C}_{0}=$ number of microorganisms before the disinfection process (cfu/sample);

$\mu_{3}=$ reduction rate calculated using the delayed ChickWatson model $(1 / \mathrm{h})$;

$\mathrm{t}=$ disinfection time $(\mathrm{h})$;

$t_{s}=$ time of the shoulder part $(h)$.

An ANOVA statistical analysis was performed to assess the statistically significant difference between the number of microorganisms on the samples before and after the disinfection. All mathematical calculations were made using the computer programs Microsoft Excel and Origin 6.1.

\section{Results}

The quantitative analysis of microbial contamination of a car air filter showed that after one year of use, the number of bacteria equalled $1.1 \times 10^{3}-1.3 \times 10^{4} \mathrm{cfu} /$ $\mathrm{cm}^{2}$, while the number of fungi was higher - from $7.0 \times 10^{4}-4.0 \times 10^{5} \mathrm{cfu} / \mathrm{cm}^{2}$. The microorganisms isolated from the filter are the bacteria Cladosporium herbarum (isolation frequency: 100\%), Staphylococcus cohnii (100\%), Rhodotorula glutinis (83.3\%), Aspergillus niger (66.6\%), Bacillus megaterium (33.3\%), Micrococcus sp. (16.7\%) and Cryptococcus laurenti (3.0\%). The microorganisms S. cohnii, C. herbarum and R.glutinis were isolated the most frequently, and so were used in the following experiments.

The numbers of bacteria during the disinfection process are presented in Table I. This shows a comparison between the number of bacteria at $77 \%$ and $49 \%$ air relative humidity. It can be seen that there was no autonomous death, or the reduction level was low $(<40 \%)$, in the control samples for both RH conditions. The number of microorganisms decreases during the $3 \mathrm{~h}$ disinfection process. The reduction degree for $77 \%$ RH is equal to $99.8 \%, 100 \%$ and $100 \%$ for S. aureus (ATCC), E. coli (ATCC) and S.cohnii (from filter), respectively. Slightly lower numbers were obtained for $49 \%$ RH: $99.0 \%, 99.7 \%$ and $100 \%$ for S. aureus, $S$. cohnii and E. coli respectively. It can be easily seen in the second hour of the process that, as was expected, the higher air relative humidity (77\%) brought about higher degrees of reduction (about 5\%). For S. aureus, the time to obtain $99 \%$ microorganism reduction was $3 \mathrm{~h}$ for both RH. In the case of E. coli, this time was $3 \mathrm{~h}$ for $\mathrm{RH}=49 \%$, but $2 \mathrm{~h}$ for $\mathrm{RH}=77 \%$; for S. cohnii, $99 \%$ reduction was obtained in $2 \mathrm{~h}$ for $\mathrm{RH}=49 \%$ and in only $1 \mathrm{~h}$ for $\mathrm{RH}=77 \%$. It was noted that the most sensitive microorganisms turned out to be the environment isolate S. cohnii, then the ATCC strains E. coli and $S$. aureus. All samples were significantly different from the sample at time 0 .

In the case of fungi (Table III), it can be seen that there was no autonomous death in the control samples of yeasts R.glutinis, and hence the control process was carried out for 6 hours. For the moulds A. niger and C. herbarum, autonomous death was observed from the second hour of the control and disinfection process. During the disinfection process, the most sensitive were strains isolated from car filters, yeasts $R$. glutinis and mould C. herbarum, for which after 6 hours the number of microorganisms decreased to $0 \mathrm{cfu} / \mathrm{sam}$ ple, giving a $100 \%$ reduction. A time of only 6 hours was necessary to obtain a $99.9 \%$ reduction. The mould A. niger (ATCC) was the most resistant, the $99.9 \%$ reduction being achieved after 24 hours of disinfection. All samples were significantly different from the sample at time 0 .

Table III and Figures 1-3 presents the rates of reduction in microorganism numbers calculated for all microorganisms with three methods: mathematical fitting, Chick-Watson model and delayed Chick-Watson model. The calculated bacterial reduction rates during disinfection, using mathematical fitting $\left(\mu_{1}\right)$, for $\mathrm{RH}=77 \%$ ranged from $-9.1 \times 10^{4}$ to $-1.0 \times 10^{7} \mathrm{cfu} / \mathrm{h}$, depending on the microorganism. For the condition $\mathrm{RH}=49 \%$ the values obtained are lower, from $-9.8 \times 10^{5}$ to $-3.0 \times$ $10^{7} \mathrm{cfu} / \mathrm{h}$. This suggests that the death rate is lower for lower relative air humidity. In the case of reduction rates calculated using the Chick-Watson model $\left(\mu_{2}\right)$, similarly values fluctuated from $-9.0 \times 10^{-1}$ to $-2.9 \times 10^{0} \mathrm{1} / \mathrm{h}$ for $\mathrm{RH}=77 \%$ and from $-6.7 \times 10^{-1}$ to $-3.1 \times 10^{0} 1 / \mathrm{h}$ for $\mathrm{RH}=49 \%$ were obtained. The reduction rates with the delayed Chick-Watson model $\left(\mu_{3}\right)$ can be calculated only for microorganisms for which the degradation process regions (shoulder, log-linear) are clearly visible. In this study, only under condition $\mathrm{RH}=77 \%$, two bacteria had the shoulder region. The reduction rates were equal to $-7.6 \times 10^{-1}$ for E. coli and $-5.4 \times 10^{0} 1 / \mathrm{h}$ for S. cohnii.

As regards fungi, the obtained values are lower due to the slower degradation process. Rates from mathematical fitting $\left(\mu_{1}\right)$ ranged from $-5.1 \times 10^{3} \mathrm{cfu} / \mathrm{h}$ to $-3.0 \times 10^{4} \mathrm{cfu} / \mathrm{h}$, and those from the Chick-Watson model ranged from $-1.3 \times 10^{-1} 1 / \mathrm{h}$ to $-4.4 \times 10^{-1} 1 / \mathrm{h}$. Only for the mould $A$. niger was a shoulder region in 
Table I

Number of bacteria during photocatalytic ionisation disinfection and control process with $\mathrm{RH}_{\mathrm{av}}=77 \%$ and $\mathrm{RH}_{\mathrm{av}}=49 \%$ on filter materials .

\begin{tabular}{|c|c|c|c|c|c|c|c|c|c|}
\hline \multirow{3}{*}{$\begin{array}{l}\text { Species } \\
\text { origin }\end{array}$} & \multirow{3}{*}{$\begin{array}{c}\text { Time } \\
\text { (h) }\end{array}$} & \multicolumn{4}{|c|}{$\mathrm{RH}_{\mathrm{av}}=77 \%$} & \multicolumn{4}{|c|}{$\mathrm{RH}_{\mathrm{av}}=49 \%$} \\
\hline & & \multicolumn{2}{|c|}{ Control process } & \multicolumn{2}{|c|}{ Disinfection process } & \multicolumn{2}{|c|}{ Control process } & \multicolumn{2}{|c|}{ Disinfection process } \\
\hline & & $\begin{array}{c}\text { Number of } \\
\text { microorganisms } \\
\text { (cfu/sample) }\end{array}$ & $\begin{array}{c}\mathrm{R} \\
(\%)\end{array}$ & \begin{tabular}{|c|}
$\begin{array}{c}\text { Number of } \\
\text { microorganisms } \\
\text { (cfu/sample })\end{array}$
\end{tabular} & $\begin{array}{c}\mathrm{R} \\
(\%)\end{array}$ & $\begin{array}{c}\text { Number of } \\
\text { microorganisms } \\
\text { (cfu/sample) }\end{array}$ & $\begin{array}{c}\mathrm{R} \\
(\%)\end{array}$ & $\begin{array}{c}\text { Number of } \\
\text { microorganisms } \\
\text { (cfu/sample) }\end{array}$ & $\begin{array}{c}\mathrm{R} \\
(\%)\end{array}$ \\
\hline \multirow[t]{8}{*}{$\begin{array}{l}\text { Staphylococcus aureus } \\
\text { (ATCC) }\end{array}$} & 0 & $\begin{array}{l}\text { Av: } 1.53 \times 10^{5} \\
\text { SD: } 2.84 \times 10^{4}\end{array}$ & 0.0 & $\begin{array}{l}\text { Av: } 3.97 \times 10^{5} \\
\text { SD: } 4.08 \times 10^{5}\end{array}$ & 0.0 & $\begin{array}{l}\text { Av: } 1.82 \times 10^{6} \\
\text { SD: } 7.10 \times 10^{5}\end{array}$ & 0.0 & $\begin{array}{l}\text { Av: } 2.27 \times 10^{5} \\
\text { SD: } 3.08 \times 10^{5}\end{array}$ & 0.0 \\
\hline & 0.08 & $\begin{array}{l}\text { Av: } 1.76 \times 10^{5 *} \\
\text { SD: } 1.88 \times 10^{4}\end{array}$ & 0.0 & $\begin{array}{l}\text { Av: } 1.76 \times 10^{5 *} \\
\text { SD: } 1.84 \times 10^{4}\end{array}$ & 55.7 & $\begin{array}{l}\text { Av: } 1.60 \times 10^{6 *} \\
\text { SD: } 2.59 \times 10^{5}\end{array}$ & 12.3 & $\begin{array}{l}\text { Av: } 1.77 \times 10^{6 *} \\
\text { SD: } 1.68 \times 10^{6}\end{array}$ & 22.0 \\
\hline & 0.25 & $\begin{array}{l}\text { Av: } 2.76 \times 10^{5 *} \\
\text { SD: } 3.23 \times 10^{4}\end{array}$ & 0.0 & $\begin{array}{l}\text { Av: } 1.72 \times 10^{5 *} \\
\text { SD: } 8.59 \times 10^{4}\end{array}$ & 56.7 & $\begin{array}{l}\text { Av: } 3.04 \times 10^{6 *} \\
\text { SD: } 2.00 \times 10^{6}\end{array}$ & 0.0 & $\begin{array}{l}\text { Av: } 1.51 \times 10^{6 *} \\
\text { SD: } 6.16 \times 10^{5}\end{array}$ & 33.7 \\
\hline & 0.50 & $\begin{array}{l}\text { Av: } 3.45 \times 10^{5 *} \\
\text { SD: } 1.63 \times 10^{4}\end{array}$ & 0.0 & $\begin{array}{l}\text { Av: } 1.60 \times 10^{5 *} \\
\text { SD: } 1.98 \times 10^{5}\end{array}$ & 59.7 & $\begin{array}{l}\text { Av: } 2.45 \times 10^{6 *} \\
\text { SD: } 1.01 \times 10^{6}\end{array}$ & 0.0 & $\begin{array}{l}\text { Av: } 1.46 \times 10^{6 *} \\
\text { SD: } 7.78 \times 10^{5}\end{array}$ & 35.8 \\
\hline & 0.75 & $\begin{array}{l}\text { Av: } 3.44 \times 10^{5 *} \\
\text { SD: } 6.34 \times 10^{4}\end{array}$ & 0.0 & $\begin{array}{l}\text { Av: } 1.42 \times 10^{5 *} \\
\text { SD: } 2.77 \times 10^{4}\end{array}$ & 64.3 & $\begin{array}{l}\text { Av: } 1.27 \times 10^{6 *} \\
\text { SD: } 1.74 \times 10^{5}\end{array}$ & 30.2 & $\begin{array}{l}\text { Av: } 8.73 \times 10^{5 *} \\
\text { SD: } 1.97 \times 10^{5}\end{array}$ & 61.6 \\
\hline & 1.00 & $\begin{array}{l}\text { Av: } 4.31 \times 10^{5 *} \\
\text { SD: } 7.07 \times 10^{4}\end{array}$ & 0.0 & $\begin{array}{l}\text { Av: } 1.33 \times 10^{5 *} \\
\text { SD: } 1.14 \times 10^{5}\end{array}$ & 66.4 & $\begin{array}{l}\text { Av: } 2.06 \times 10^{6 *} \\
\text { SD: } 7.61 \times 10^{5}\end{array}$ & 0.0 & $\begin{array}{l}\text { Av: } 8.38 \times 10^{5 *} \\
\text { SD: } 1.64 \times 10^{5}\end{array}$ & 63.2 \\
\hline & 2.00 & $\begin{array}{l}\text { Av: } 4.20 \times 10^{5 *} \\
\text { SD: } 6.96 \times 10^{4}\end{array}$ & 0.0 & $\begin{array}{l}\text { Av: } 3.68 \times 10^{4 \star} \\
\text { SD: } 2.30 \times 10^{4}\end{array}$ & 90.7 & $\begin{array}{l}\text { Av: } 2.02 \times 10^{6 *} \\
\text { SD: } 1.45 \times 10^{5}\end{array}$ & 0.0 & $\begin{array}{l}\text { Av: } 1.06 \times 10^{5 *} \\
\text { SD: } 1.18 \times 10^{5}\end{array}$ & 95.4 \\
\hline & 3.00 & $\begin{array}{l}\text { Av: } 4.66 \times 10^{5 *} \\
\text { SD: } 5.68 \times 10^{4}\end{array}$ & 0.0 & $\begin{array}{l}\text { Av: } 7.73 \times 10^{2 *} \\
\text { SD: } 1.34 \times 10^{3}\end{array}$ & 99.8 & $\begin{array}{l}\text { Av: } 2.31 \times 10^{6 *} \\
\text { SD: } 6.18 \times 10^{5}\end{array}$ & 0.0 & $\begin{array}{l}\text { Av: } 2.23 \times 10^{4 *} \\
\text { SD: } 1.21 \times 10^{4}\end{array}$ & 99.0 \\
\hline \multirow[t]{8}{*}{ Escherichia coli (ATCC) } & 0 & $\begin{array}{l}\text { Av: } 1.31 \times 10^{7} \\
\text { SD: } 9.41 \times 10^{6}\end{array}$ & 0.0 & $\begin{array}{l}\text { Av: } 1.23 \times 10^{7} \\
\text { SD: } 7.50 \times 10^{5}\end{array}$ & 0.0 & $\begin{array}{l}\text { Av: } 2.86 \times 10^{7} \\
\text { SD: } 4.73 \times 10^{6}\end{array}$ & 0.0 & $\begin{array}{l}\text { Av: } 6.11 \times 10^{7} \\
\text { SD: } 2.54 \times 10^{7}\end{array}$ & 0.0 \\
\hline & 0.08 & $\begin{array}{l}\text { Av: } 1.70 \times 10^{7 *} \\
\text { SD: } 4.46 \times 10^{6}\end{array}$ & 0.0 & $\begin{array}{l}\text { Av: } 1.17 \times 10^{7 *} \\
\text { SD: } 8.40 \times 10^{6}\end{array}$ & 5.1 & $\begin{array}{l}\text { Av: } 3.42 \times 10^{7 *} \\
\text { SD: } 6.90 \times 10^{6}\end{array}$ & 0.0 & $\begin{array}{l}\text { Av: } 5.85 \times 10^{7 *} \\
\text { SD: } 1.39 \times 10^{7}\end{array}$ & 4.3 \\
\hline & 0.25 & $\begin{array}{l}\text { Av: } 8.97 \times 10^{6 *} \\
\text { SD: } 1.30 \times 10^{7}\end{array}$ & 31.4 & $\begin{array}{l}\text { Av: } 7.05 \times 10^{6 *} \\
\text { SD: } 3.85 \times 10^{6}\end{array}$ & 42.8 & $\begin{array}{l}\text { Av: } 3.17 \times 10^{7 *} \\
\text { SD: } 1.60 \times 10^{6}\end{array}$ & 0.0 & $\begin{array}{l}\text { Av: } 4.18 \times 10^{7 *} \\
\text { SD: } 2.06 \times 10^{6}\end{array}$ & 31.6 \\
\hline & 0.50 & $\begin{array}{l}\text { Av: } 1.74 \times 10^{7 *} \\
\text { SD: } 4.21 \times 10^{6}\end{array}$ & 0.0 & $\begin{array}{l}\text { Av: } 6.86 \times 10^{6 *} \\
\text { SD: } 1.79 \times 10^{6}\end{array}$ & 44.4 & $\begin{array}{l}\text { Av: } 1.77 \times 10^{7 *} \\
\text { SD: } 3.23 \times 10^{6}\end{array}$ & 38.3 & $\begin{array}{l}\text { Av: } 3.75 \times 10^{7 *} \\
\text { SD: } 2.08 \times 10^{7}\end{array}$ & 38.6 \\
\hline & 0.75 & $\begin{array}{l}\text { Av: } 1.85 \times 10^{7 *} \\
\text { SD: } 1.77 \times 10^{6}\end{array}$ & 0.0 & $\begin{array}{l}\text { Av: } 6.57 \times 10^{6 *} \\
\text { SD: } 2.25 \times 10^{6}\end{array}$ & 46.7 & $\begin{array}{l}\text { Av: } 2.17 \times 10^{7 *} \\
\text { SD: } 5.07 \times 10^{6}\end{array}$ & 24.3 & $\begin{array}{l}\text { Av: } 3.52 \times 10^{7 *} \\
\text { SD: } 5.50 \times 10^{6}\end{array}$ & 42.4 \\
\hline & 1.00 & $\begin{array}{l}\text { Av: } 1.03 \times 10^{7 *} \\
\text { SD: } 1.32 \times 10^{7}\end{array}$ & 21.0 & $\begin{array}{l}\text { Av: } 5.17 \times 10^{6 *} \\
\text { SD: } 9.19 \times 10^{5}\end{array}$ & 58.0 & $\begin{array}{l}\text { Av: } 2.19 \times 10^{7 *} \\
\text { SD: } 8.08 \times 10^{5}\end{array}$ & 23.6 & $\begin{array}{l}\text { Av: } 3.47 \times 10^{7 *} \\
\text { SD: } 1.00 \times 10^{7}\end{array}$ & 43.2 \\
\hline & 2.00 & $\begin{array}{l}\text { Av: } 2.36 \times 10^{7 *} \\
\text { SD: } 3.87 \times 10^{6}\end{array}$ & 0.0 & $\begin{array}{l}\text { Av: } 4.13 \times 10^{5 *} \\
\text { SD: } 4.95 \times 10^{5}\end{array}$ & 96.7 & $\begin{array}{l}\text { Av: } 3.79 \times 10^{7 *} \\
\text { SD: } 1.37 \times 10^{7}\end{array}$ & 0.0 & $\begin{array}{l}\text { Av: } 1.41 \times 10^{5 *} \\
\text { SD: } 2.26 \times 10^{5}\end{array}$ & 99.8 \\
\hline & \begin{tabular}{|l|}
3.00 \\
\end{tabular} & $\begin{array}{l}\text { Av: } 2.01 \times 10^{7 *} \\
\text { SD: } 7.85 \times 10^{6}\end{array}$ & 0.0 & $\begin{array}{l}\text { Av: } 3.33 \times 10^{3 *} \\
\text { SD: } 2.23 \times 10^{3}\end{array}$ & 100.0 & $\begin{array}{l}\text { Av: } 2.73 \times 10^{7 *} \\
\text { SD: } 6.65 \times 10^{6}\end{array}$ & 4.8 & $\begin{array}{l}\text { Av: } 5.41 \times 10^{3 *} \\
\text { SD: } 6.47 \times 10^{3}\end{array}$ & 100.0 \\
\hline \multirow[t]{8}{*}{$\begin{array}{l}\text { Staphylococcus cohnii } \\
\text { (isolate) }\end{array}$} & 0 & $\begin{array}{l}\text { Av: } 5.86 \times 10^{6} \\
\text { SD: } 5.84 \times 10^{5}\end{array}$ & 0.0 & $\begin{array}{l}\text { Av: } 7.63 \times 10^{6} \\
\text { SD: } 2.22 \times 10^{6}\end{array}$ & 0.0 & $\begin{array}{l}\text { Av: } 1.54 \times 10^{6} \\
\text { SD: } 1.44 \times 10^{5}\end{array}$ & 0.0 & $\begin{array}{l}\text { Av: } 2.01 \times 10^{6} \\
\text { SD: } 5.97 \times 10^{4}\end{array}$ & 0.0 \\
\hline & 0.08 & $\begin{array}{l}\text { Av: } 6.09 \times 10^{6 *} \\
\text { SD: } 2.27 \times 10^{6}\end{array}$ & 0.0 & $\begin{array}{l}\text { Av: } 6.50 \times 10^{6 *} \\
\text { SD: } 3.73 \times 10^{6}\end{array}$ & 14.9 & $\begin{array}{l}\text { Av: } 1.70 \times 10^{6 *} \\
\text { SD: } 3.06 \times 10^{5}\end{array}$ & 0.0 & $\begin{array}{l}\text { Av: } 1.77 \times 10^{6 *} \\
\text { SD: } 9.03 \times 10^{5}\end{array}$ & 11.7 \\
\hline & 0.25 & $\begin{array}{l}\text { Av: } 7.79 \times 10^{6 *} \\
\text { SD: } 3.59 \times 10^{6}\end{array}$ & 0.0 & $\begin{array}{l}\text { Av: } 6.36 \times 10^{6 *} \\
\text { SD: } 2.04 \times 10^{6}\end{array}$ & 16.6 & $\begin{array}{l}\text { Av: } 1.93 \times 10^{6 *} \\
\text { SD: } 4.09 \times 10^{5}\end{array}$ & 0.0 & $\begin{array}{l}\text { Av: } 5.45 \times 10^{5 *} \\
\text { SD: } 3.76 \times 10^{5}\end{array}$ & 72.8 \\
\hline & 0.50 & $\begin{array}{l}\text { Av: } 9.32 \times 10^{6 *} \\
\text { SD: } 6.21 \times 10^{6}\end{array}$ & 0.0 & $\begin{array}{l}\text { Av: } 2.80 \times 10^{5 *} \\
\text { SD: } 1.30 \times 10^{5}\end{array}$ & 96.3 & $\begin{array}{l}\text { Av: } 2.53 \times 10^{6 *} \\
\text { SD: } 6.68 \times 10^{5}\end{array}$ & 0.0 & $\begin{array}{l}\text { Av: } 5.73 \times 10^{4 *} \\
\text { SD: } 2.40 \times 10^{4}\end{array}$ & 97.2 \\
\hline & 0.75 & $\begin{array}{l}\text { Av: } 7.56 \times 10^{6 *} \\
\text { SD: } 1.29 \times 10^{7}\end{array}$ & 0.0 & $\begin{array}{l}\text { Av: } 2.58 \times 10^{5 *} \\
\text { SD: } 2.96 \times 10^{5}\end{array}$ & 96.6 & $\begin{array}{l}\text { Av: } 1.39 \times 10^{6 *} \\
\text { SD: } 1.54 \times 10^{5}\end{array}$ & 9.9 & $\begin{array}{l}\text { Av: } 1.70 \times 10^{4 *} \\
\text { SD: } 1.47 \times 10^{4}\end{array}$ & 99.2 \\
\hline & 1.00 & $\begin{array}{l}\text { Av: } 8.04 \times 10^{6 *} \\
\text { SD: } 7.68 \times 10^{6}\end{array}$ & 0.0 & $\begin{array}{l}\text { Av: } 1.73 \times 10^{5 *} \\
\text { SD: } 1.06 \times 10^{5}\end{array}$ & 97.7 & $\begin{array}{l}\text { Av: } 1.78 \times 10^{6 *} \\
\text { SD: } 6.60 \times 10^{5}\end{array}$ & 0.0 & $\begin{array}{l}\text { Av: } 1.18 \times 10^{4 *} \\
\text { SD: } 9.18 \times 10^{2}\end{array}$ & 99.4 \\
\hline & 2.00 & $\begin{array}{l}\text { Av: } 2.81 \times 10^{7 *} \\
\text { SD: } 4.26 \times 10^{6}\end{array}$ & 0.0 & $\begin{array}{l}\text { Av: } 0.0^{*} \\
\text { SD: } 0.0\end{array}$ & 100.0 & $\begin{array}{l}\text { Av: } 2.00 \times 10^{6 *} \\
\text { SD: } 4.54 \times 10^{5}\end{array}$ & 0.0 & $\begin{array}{l}\text { Av: } 9.66 \times 10^{3 *} \\
\text { SD: } 3.79 \times 10^{3}\end{array}$ & 99.5 \\
\hline & 3.00 & $\begin{array}{l}\text { Av: } 2.74 \times 10^{7 *} \\
\text { SD: } 1.02 \times 10^{7}\end{array}$ & 0.0 & $\begin{array}{l}\text { Av: } 0.0^{*} \\
\text { SD: } 0.0\end{array}$ & 100.0 & $\begin{array}{l}\text { Av: } 1.55 \times 10^{6 *} \\
\text { SD: } 2.27 \times 10^{5}\end{array}$ & 0.0 & $\begin{array}{l}\text { Av: } 6.33 \times 10^{3 *} \\
\text { SD: } 1.44 \times 10^{3}\end{array}$ & \begin{tabular}{|l|l}
99.7 \\
\end{tabular} \\
\hline
\end{tabular}

* significantly different to the sample at the beginning time $(0 \mathrm{~h})$, Anova with the significance level $\mathrm{P}<0.05$

$\mathrm{Av}$ - arithmetic mean; SD - standard deviation; $\mathrm{R}$ - reduction of microorganism number 
Table II

Number of fungi during photocatalytic ionisation disinfection and control process at $\mathrm{RH}_{\mathrm{av}}=53 \%$ on filter materials.

\begin{tabular}{|c|c|c|c|c|c|}
\hline \multirow[b]{2}{*}{ Species origin } & \multirow[b]{2}{*}{$\begin{array}{l}\text { Time } \\
(\mathrm{h})\end{array}$} & \multicolumn{2}{|l|}{ Control } & \multicolumn{2}{|l|}{ Disinfection } \\
\hline & & $\begin{array}{c}\text { Number of microorganisms } \\
\text { (cfu/sample) }\end{array}$ & $\begin{array}{c}\mathrm{R} \\
(\%)\end{array}$ & $\begin{array}{c}\text { Number of microorganisms } \\
\text { (cfu/sample) }\end{array}$ & $\begin{array}{c}\mathrm{R} \\
(\%)\end{array}$ \\
\hline \multirow[t]{7}{*}{ Rhodotorula glutinis (isolate) } & 0 & $\begin{array}{l}\text { Av: } 1.47 \times 10^{5} \\
\text { SD: } 1.46 \times 10^{4}\end{array}$ & 0.0 & $\begin{array}{l}\text { Av: } 1.85 \times 10^{5} \\
\text { SD: } 7.07 \times 10^{2}\end{array}$ & 0.0 \\
\hline & 2 & $\begin{array}{l}\text { Av: } 1.41 \times 10^{5 *} \\
\text { SD: } 1.08 \times 10^{4}\end{array}$ & 3.8 & $\begin{array}{l}\text { Av: } 9.90 \times 10^{4 *} \\
\text { SD: } 3.54 \times 10^{4}\end{array}$ & 46.3 \\
\hline & 4 & $\begin{array}{l}\text { Av: } 1.41 \times 10^{5 *} \\
\text { SD: } 3.75 \times 10^{4}\end{array}$ & 3.9 & $\begin{array}{l}\text { Av: } 5.51 \times 10^{4 *} \\
\text { SD: } 6.72 \times 10^{3}\end{array}$ & 70.1 \\
\hline & 6 & $\begin{array}{l}\text { Av: } 1.42 \times 10^{5 *} \\
\text { SD: } 8.60 \times 10^{3}\end{array}$ & 2.8 & $\begin{array}{l}\text { Av: } 0.0^{*} \\
\text { SD: } 0.0\end{array}$ & 100.0 \\
\hline & 8 & nt & - & $\begin{array}{l}\text { Av: } 0.0^{*} \\
\text { SD: } 0.0\end{array}$ & 100.0 \\
\hline & 12 & nt & - & $\begin{array}{l}\text { Av: } 0.0^{*} \\
\text { SD: } 0.0\end{array}$ & 100.0 \\
\hline & 24 & nt & - & $\begin{array}{l}\text { Av: } 0.0^{*} \\
\text { SD: } 0.0\end{array}$ & 100.0 \\
\hline \multirow[t]{7}{*}{ Aspergillus niger (ATCC) } & 0 & $\begin{array}{l}\text { Av: } 3.42 \times 10^{4} \\
\text { SD: } 5.73 \times 10^{3}\end{array}$ & 0.0 & $\begin{array}{l}\text { Av: } 8.81 \times 10^{4} \\
\text { SD: } 1.57 \times 10^{4}\end{array}$ & 0.0 \\
\hline & 2 & $\begin{array}{l}\text { Av: } 2.86 \times 10^{4 \star} \\
\text { SD: } 4.17 \times 10^{3}\end{array}$ & 16.4 & $\begin{array}{l}\text { Av: } 8.63 \times 10^{4 *} \\
\text { SD: } 2.24 \times 10^{4}\end{array}$ & 2.0 \\
\hline & 4 & $\begin{array}{l}\text { Av: } 2.44 \times 10^{4 *} \\
\text { SD: } 2.17 \times 10^{3}\end{array}$ & 28.6 & $\begin{array}{l}\text { Av: } 4.43 \times 10^{4 \star} \\
\text { SD: } 1.52 \times 10^{4}\end{array}$ & 49.7 \\
\hline & 6 & $\begin{array}{l}\text { Av: } 1.72 \times 10^{4 \star} \\
\text { SD: } 6.95 \times 10^{2}\end{array}$ & 49.8 & $\begin{array}{l}\text { Av: } 2.30 \times 10^{4 *} \\
\text { SD: } 2.88 \times 10^{3}\end{array}$ & 73.9 \\
\hline & 8 & $\begin{array}{l}\text { Av: } 3.98 \times 10^{3 *} \\
\text { SD: } 9.19 \times 10^{2}\end{array}$ & 88.4 & $\begin{array}{l}\text { Av: } 1.92 \times 10^{4 *} \\
\text { SD: } 1.02 \times 10^{4}\end{array}$ & 78.2 \\
\hline & 12 & $\begin{array}{l}\text { Av: } 2.65 \times 10^{3 *} \\
\text { SD: } 9.55 \times 10^{2}\end{array}$ & 92.3 & $\begin{array}{l}\text { Av: } 8.50 \times 10^{2 *} \\
\text { SD: } 7.07 \times 10^{0}\end{array}$ & 99.0 \\
\hline & 24 & $\begin{array}{l}\text { Av: } 2.13 \times 10^{3 *} \\
\text { SD: } 0.0\end{array}$ & 93.8 & $\begin{array}{l}\text { Av: } 1.00 \times 10^{2 *} \\
\text { SD: } 7.78 \times 10^{0}\end{array}$ & 99.9 \\
\hline \multirow[t]{7}{*}{ Cladosporium herbarum (isolate) } & 0 & $\begin{array}{l}\text { Av: } 3.02 \times 10^{4} \\
\text { SD: } 3.29 \times 10^{3}\end{array}$ & 0.0 & $\begin{array}{l}\text { Av: } 3.32 \times 10^{4} \\
\text { SD: } 1.78 \times 10^{3}\end{array}$ & 0.0 \\
\hline & 2 & $\begin{array}{l}\text { Av: } 1.08 \times 10^{4 *} \\
\text { SD: } 8.82 \times 10^{3}\end{array}$ & 64.3 & $\begin{array}{l}\text { Av: } 3.15 \times 10^{4 *} \\
\text { SD: } 1.08 \times 10^{4}\end{array}$ & 64.2 \\
\hline & 4 & $\begin{array}{l}\text { Av: } 2.69 \times 10^{3 *} \\
\text { SD: } 1.18 \times 10^{3}\end{array}$ & 91.1 & $\begin{array}{l}\text { Av: } 2.88 \times 10^{4 *} \\
\text { SD: } 1.58 \times 10^{4}\end{array}$ & 67.4 \\
\hline & 6 & $\begin{array}{l}\text { Av: } 4.16 \times 10^{3 *} \\
\text { SD: } 3.36 \times 10^{2}\end{array}$ & 86.2 & $\begin{array}{l}\text { Av: } 7.50 \times 10^{1 \star} \\
\text { SD: } 3.54 \times 10^{1}\end{array}$ & 99.9 \\
\hline & 8 & $\mathrm{nt}$ & - & $\begin{array}{l}\text { Av: } 0.0^{*} \\
\text { SD: } 0.0\end{array}$ & 100.0 \\
\hline & 12 & $\mathrm{nt}$ & - & $\begin{array}{l}\text { Av: } 0.0^{*} \\
\text { SD: } 0.0\end{array}$ & 100.0 \\
\hline & 24 & $\mathrm{nt}$ & - & $\begin{array}{l}\text { Av: } 0.0^{*} \\
\text { SD: } 0.0\end{array}$ & 100.0 \\
\hline
\end{tabular}

* significantly different to the sample at the beginning time $(0 \mathrm{~h})$, Anova with the significance level $\mathrm{P}<0.05$ Av - arithmetic mean; SD - standard deviation; R - reduction of microorganism number $\mathrm{nt}$ - not tested (reason: no microorganisms in the sample after disinfection process)

the microbial degradation process observed, and the calculated reduction rate equalled $-2.0 \times 10^{-1} 1 / \mathrm{h}$.

Comparison of the mathematical models of microorganism degradation (Figures 1-3) was performed for three microorganisms (S. cohnii, E. coli, A. niger) for which a shoulder region occurred in the microorganism degradation - the reduction of microorganism numbers started only after some time. It can be 


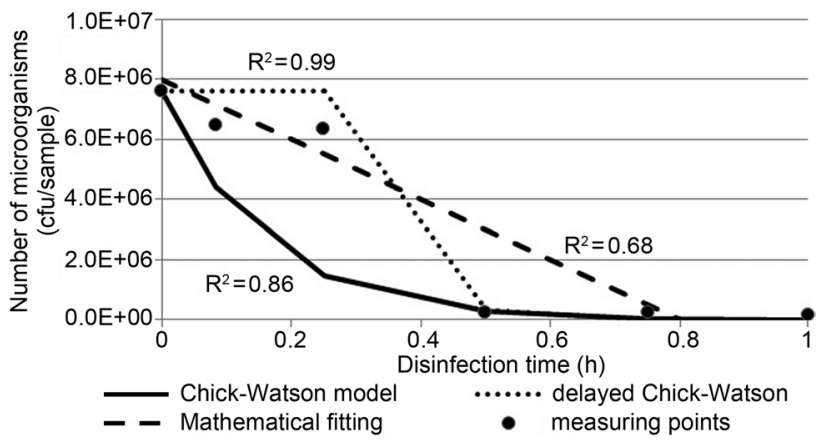

Fig. 1. Comparison of mathematical models describing the degradation process of $S$. cohnii.

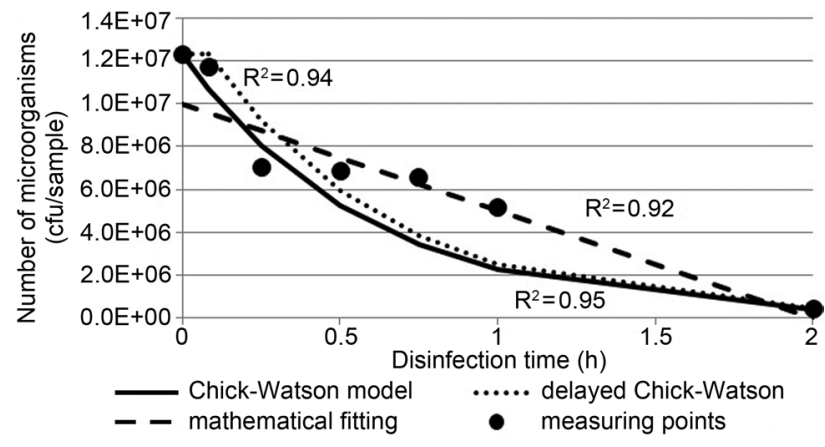

Fig. 2. Comparison of mathematical models describing the degradation process of E. coli.

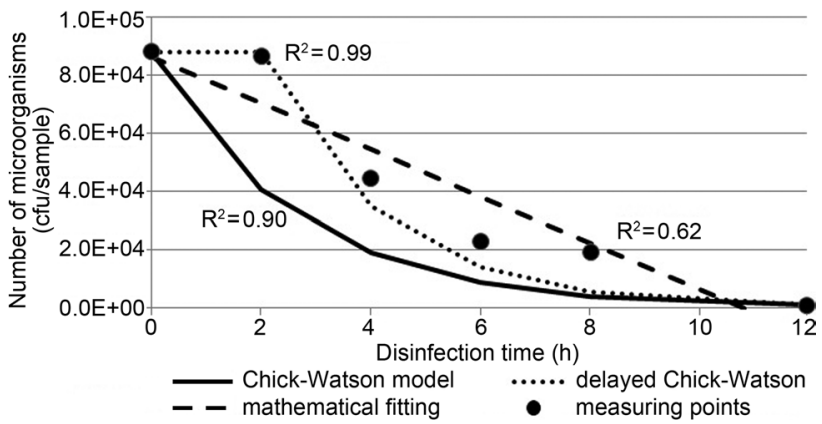

Fig. 3. Comparison of mathematical models describing the degradation process of $A$. niger.

Table III

Photocatalytic ionisation disinfection effectiveness on filter materials.

\begin{tabular}{|c|c|c|c|c|c|}
\hline \multirow{2}{*}{ Bacteria } & \multirow{2}{*}{$\begin{array}{l}\text { Microorganisms } \\
\text { reduction rate }\end{array}$} & \multicolumn{2}{|c|}{$\mathrm{RH}_{\mathrm{av}}=77 \%$} & \multicolumn{2}{|c|}{$\mathrm{RH}_{\mathrm{av}}=49 \%$} \\
\hline & & Control & Disinfection & Control & Disinfection \\
\hline \multirow[t]{3}{*}{ S. aureus } & $\mu_{1}(\mathrm{cfu} / \mathrm{h})$ & $9.2 \times 10^{4}$ & $-9.1 \times 10^{4}$ & $5.1 \times 10^{4}$ & $-9.8 \times 10^{5}$ \\
\hline & $\mu_{2}(1 / h)$ & $1.6 \times 10^{-1}$ & $-9.0 \times 10^{-1}$ & $3.4 \times 10^{-2}$ & $-6.7 \times 10^{-1}$ \\
\hline & $\mu_{3}(1 / h)$ & - & - & - & - \\
\hline \multirow[t]{3}{*}{ E. coli } & $\mu_{1}(\mathrm{cfu} / \mathrm{h})$ & $3.0 \times 10^{6}$ & $-5.0 \times 10^{6}$ & $7.6 \times 10^{5}$ & $-3.0 \times 10^{7}$ \\
\hline & $\mu_{2}(1 / h)$ & $6.2 \times 10^{-2}$ & $-7.4 \times 10^{-1}$ & $-7.1 \times 10^{-3}$ & $-1.3 \times 10^{0}$ \\
\hline & $\mu_{3}(1 / h)$ & - & $-7.6 \times 10^{-1}$ & - & - \\
\hline \multirow[t]{3}{*}{ S. cohnii } & $\mu_{1}(\mathrm{cfu} / \mathrm{h})$ & $8.0 \times 10^{6}$ & $-1.0 \times 10^{7}$ & $-4.2 \times 10^{4}$ & $-4.0 \times 10^{6}$ \\
\hline & $\mu_{2}(1 / h)$ & $2.2 \times 10^{-1}$ & $-2.9 \times 10^{0}$ & $2.1 \times 10^{-4}$ & $-3.1 \times 10^{0}$ \\
\hline & $\mu_{3}(1 / h)$ & - & $-5.4 \times 10^{0}$ & - & - \\
\hline \multirow{2}{*}{ Fungi } & & \multicolumn{4}{|c|}{$\mathrm{RH}_{\mathrm{av}}=53 \%$} \\
\hline & & \multicolumn{2}{|c|}{ Control } & \multicolumn{2}{|c|}{ Disinfection } \\
\hline \multirow[t]{3}{*}{ R.glutinis } & $\mu_{1}(\mathrm{cfu} / \mathrm{h})$ & \multicolumn{2}{|c|}{$-6.2 \times 10^{2}$} & \multicolumn{2}{|c|}{$-3.0 \times 10^{4}$} \\
\hline & $\mu_{2}(1 / h)$ & \multicolumn{2}{|c|}{$-2.1 \times 10^{-3}$} & \multicolumn{2}{|c|}{$-1.3 \times 10^{-1}$} \\
\hline & $\mu_{3}(1 / h)$ & \multicolumn{2}{|l|}{-} & \multicolumn{2}{|l|}{-} \\
\hline \multirow[t]{3}{*}{ A. niger } & $\mu_{1}(\mathrm{cfu} / \mathrm{h})$ & \multicolumn{2}{|c|}{$-3.6 \times 10^{2}$} & \multicolumn{2}{|c|}{$-8.0 \times 10^{3}$} \\
\hline & $\mu_{2}(1 / h)$ & \multicolumn{2}{|c|}{$-5.0 \times 10^{-2}$} & \multicolumn{2}{|c|}{$-1.7 \times 10^{-1}$} \\
\hline & $\mu_{3}(1 / h)$ & \multicolumn{2}{|l|}{-} & \multicolumn{2}{|c|}{$-2.0 \times 10^{-1}$} \\
\hline \multirow[t]{3}{*}{ C. herbarum } & $\mu_{1}(\mathrm{cfu} / \mathrm{h})$ & \multicolumn{2}{|c|}{$-4.0 \times 10^{3}$} & \multicolumn{2}{|c|}{$-5.1 \times 10^{3}$} \\
\hline & $\mu_{2}(1 / h)$ & \multicolumn{2}{|c|}{$-6.9 \times 10^{-2}$} & \multicolumn{2}{|c|}{$-4.4 \times 10^{-1}$} \\
\hline & $\mu_{3}(1 / h)$ & \multicolumn{2}{|l|}{-} & \multicolumn{2}{|l|}{-} \\
\hline
\end{tabular}

$\mu_{1}$ - the rate of microbial reduction during disinfection calculated with the linear function $\mu_{2}$ - the rate of microbial reduction during disinfection calculated with the Chick-Watson model

$\mu_{3}$ - the rate of microbial reduction during disinfection calculated with the delayed Chick-Watson model - value did not calculated due to the absence of shoulder region in the microorganism degradation process needed in delayed Chick-Watson model 
noticed that the most adequate model is the delayed Chick-Watson model, for which the correlation coefficient $\mathrm{R}^{2}$ was the highest, ranging from 0.90 to 0.99 . The Chick-Watson model also matches the measuring points very well, with $\mathrm{R}^{2}$ from 0.86 to 0.95 . The worst method was mathematical fitting with a straight line $y=a x+b$, for which $R^{2}=0.62-0.92$. However, for most of the microorganisms the delayed Chick-Watson model could not be used and the simpler model would be enough for the description of microorganism disinfection death dynamics.

\section{Discussion}

The numbers of bacteria $\left(1.1 \times 10^{3}-1.3 \times 10^{4} \mathrm{cfu} /\right.$ $\left.\mathrm{cm}^{2}\right)$ and fungi $\left(7.0 \times 10^{4}-4.0 \times 10^{5} \mathrm{cfu} / \mathrm{cm}^{2}\right)$ on the used filters are very high. The concentration of microorganisms in the car interior is about $10^{3} \mathrm{cfu} / \mathrm{m}^{3}$, and most of them ( $>80 \%)$ are stopped on the car AC filters (Vonberg et al., 2010). The microorganisms isolated from the used filter, bacteria B. megaterium, Micrococcus sp. and fungi A. niger, C. herbarum, are common in the environment, whereas S. cohnii, like most staphylococci, cause internal and skin infections. C. laurentii and R. glutinis are rare human pathogens, but can cause internal infections (Vos et al., 2009). The high microbial contamination suggests the need for seasonal or constant disinfection of filter materials.

The conditions of effective photocatalytic ionisation disinfection (reduction in microorganism number $\geq 99.9 \%$ ) were established as $2-3 \mathrm{~h}$ for $\mathrm{RH}=49 \%$, $6-24 \mathrm{~h}$ for $\mathrm{RH}=53 \%$ and $2-3 \mathrm{~h}$ for $\mathrm{RH}=77 \%$, depending on the bacteria or fungi species. The efficiency of the photocatalytic ionisation disinfection method has been checked on many microorganisms in model studies, e.g. Gram-negative bacteria E.coli, Pseudomonas sp., Gram-positive bacteria Bacillus sp., Staphylococcus sp., fungi Aspergillus niger, Candida sp., Fusarium sp., Penicillium sp., viruses, protozoa, algae (Foster et al., 2011). There are no reports in the literature concerning photocatalytic ionisation disinfection of contaminated filter materials. The results presented by the authors may only be compared with the most similar method of using $\mathrm{TiO}_{2}$ films contaminated with microorganisms and irradiated with UV light. In our study, the time needed to obtain a $99.9 \%$ reduction in E. coli numbers is 3 hours. In the literature this time ranged from 1 to 24 hours, depending on the author and the details of the experiment (Kikuchi et al., 1997; Ditta et al., 2008; Dunnill et al., 2011; Foster et al., 2011). Another similar method which can be compared is the disinfection of bioaerosols in chambers with $\mathrm{TiO}_{2}$ films irradiated by UV light (Vohra et al., 2006). This method has very high efficiency, especially for bacteria: the $99.9 \%$ reduction time was $45 \mathrm{~min}$ and $1 \mathrm{~h}$ for S. aureus and E. coli. This time is $2 / 3$ shorter than that obtained in our study. In the case of fungi (A. niger), the effectiveness of disinfection of contaminated filter materials is higher than that of bioaerosols. The $99.9 \%$ reduction time is shorter by half in our study $(24 \mathrm{~h})$, which suggests that for filter materials the disinfection time should be extended.

The UV light disinfection method has similar efficiency. A reduction of $A$. niger equal to $95.0 \%$ and $99.6 \%$ after 6 hours of disinfection was obtained by placing a UV light in a Heating, Ventilation and Air Conditioning (HVAC) system (Salata et al., 2006). On the other hand, the reduction of E. coli films by UV lamps gave a reduction of $63.1-99.9 \%$ depending on the quantity of UV lamps used (Barkhudarov et al., 2008). Ultrasound is also used as a disinfection method. A 95.5\% reduction of E.coli suspension was obtained after $11.5 \mathrm{~min}$ by Limaye and Coakley (Limaye and Coakley, 1998). Therefore photocatalytic ionisation disinfection can be used as an alternative to currently used methods.

The air relative humidity has an influence on the effectiveness of the photocatalytic disinfection process. In our case, the most visible effect is in the second hour of the process for $\mathrm{RH}=77 \%$. The highest effectiveness (in the second hour) was obtained for $\mathrm{RH}=77 \%$ and equalled $90.7-100 \%$; it was higher by $0.5-4.7 \%$ than the results for $\mathrm{RH}=49 \%$. Goswami and others (Goswami et al., 1997) noticed that a RH of $50 \%$ is the most effective; the microorganism reductions obtained at lower $(\mathrm{RH}=30 \%)$ and higher $(\mathrm{RH}=85 \%)$ values were about $10 \%$ lower. It has been established that very low $\mathrm{RH}$ reduces the probability of ROS creation and cell penetration, and very high $\mathrm{RH}$ reduces the probability of microorganisms' contact with ROS and can also facilitate their regeneration and survival (Chen et al., 2010).

The studies showed that the sensitivity of microorganisms to photocatalytic ionisation disinfection is ordered as follows: Gram-positive bacteria (S. cohnii, S. aureus), Gram-negative bacteria (E. coli), yeasts (R. lutinis), and moulds (C. herbarum, A. niger). Such a ranking is confirmed in the literature (Malato et al., 2009; Foster et al., 2010; Sanchez et al., 2012).

All mathematical models used for description of the microorganism degradation process did not achieve their objective. Generally, the Chick-Watson model and mathematical model could not be exploited due to the low $(<0.9)$ correlation coefficient. The experimental data indicated that the delayed Chick-Watson model was only one acceptable for the disinfection description.

The presented disinfection method of photocatalytic ionisation can be successfully used to clean filtration materials. Noteworthy is the high efficiency in fungi number reduction, which are the greatest concern as regards microbial contamination of car AC filters and are very resistant to most disinfection methods. 


\section{Literature}

Barkhudarov E.M., N. Christofi, I.A. Kossyi, M.A. Misakyan, J. Sharp and I.M. Taktakishvili. 2008. Killing bacteria present on surfaces in films or in droplets using microwave UV lamps. World J. Microbiol. Biotechnol. 24: 761-9.

Chapman M.D. 2006. Challenges associated with indoor moulds: health effects, immune response and exposure assessment. Med. Mycol. J. 44: 529-532.

Chen F.N., X. Yang and Q. Wu. 2009. Photocatalytic oxidation of Escherichia coli, Aspergillus niger and formaldehyde under different UV irradiation conditions. Environ. Sci. Technol. 43: 4606-4611.

Chen F., X. Yang, H.K.C. Mak and D.W.T. Chan. 2010. Photocatalytic oxidation for antimicrobial control in built environment: A brief literature overview. Build. Environ. 45: 1747-1754.

Cho M., W. Choi, H. Chung and J. Yoon. 2004a. Different Inactivation Behaviors of MS-2 Phage and Escherichia coli in $\mathrm{TiO}_{2}$ Photocatalityic Disinfection. Appl. Environ. Microbiol. 71: 270-275.

Cho M., H. Chung, W. Choi and J. Yoon. 2004b. Linear correlation between inactivation of $E$. coli and $\mathrm{OH}$ radical concentration in $\mathrm{TiO}_{2}$ photocatalytic disinfection. Water. Res. 38: 1069-1077.

Dalrymple O.K., E. Stefanakos, M.A. Trotz and D.Y. Goswami. 2010. A review of the mechanisms and modeling of photocatalytic disinfection. Appl. Catal. B 98: 27-38.

Ditta I.B., A. Steele, C. Liptrot, J. Tobin, H. Tyler, H.M. Yates, D.W Sheel and H.A. Foster. 2008. Photocatalytic antimicrobial activity of thin surface films of $\mathrm{TiO}_{2}, \mathrm{CuO}$ and $\mathrm{TiO}_{2} / \mathrm{CuO}$ dual layers on Escherichia coli and bacteriophage T4. Appl. Microbiol. Biotechnol. 79: 127-133.

Dunnill C.W., K. Page, Z.A. Aiken, S. Noimark, G. Hyett, A. Kafizas, J. Pratten, M. Wilson and I.P. Parkin. 2011. Nanoparticulate silver coated-titania thin films-Photo-oxidative destruction of stearic acid under different light sources and antimicrobial effects under hospital lighting conditions. J. Photochem. Photobiol. A 220: 113-123.

Flannigan B., R.A. Samson and J.D. Miller. 2001. Microorganisms in home and indoor work environments: diversity, health impacts, investigation and control. Taylor \& Francis. London and New York. Foster H.A., D.W. Sheel, P. Sheel, P. Evans, S. Varghese, N. Rutschke and H.M. Yates. 2010. Antimicrobial activity of titania/silver and titania/copper films prepared by CVD. J. Photochem. Photobiol. A. 216: 283-289.

Foster H.A., I.B. Ditta, S. Varghese and A. Steele. 2011. Photocatalytic disinfection using titanium dioxide: spectrum and mechanism of antimicrobial activity. Appl. Microbiol. Biotechnol. 90: 1847-1868. Fujishima A. and K. Honda. 1972. Electrochemical photolysis of water at a semiconductor electrode. Nature 238: 37-38.

Fujishima A. and X. Zhang. 2006. Titanium dioxide photocatalysis: present situation and future approaches. C.R. Chim. 9: 750-760.

Gogniat G. and S. Dukan. 2007. $\mathrm{TiO}_{2}$ photocatalysis causes DNA damage via Fenton reaction-generated hydroxyl radicals during the recovery period. Appl. Environ. Microbiol. 73: 7740-7743.

Goswami D.Y., D.M. Trivedi and S.S. Block. 1997. Photocatalytic disinfection of indoor air. J. Sol. Energ-T ASME 119: 92-96.

Greist H.T., S.K. Hingorani, K. Kelley and D.Y. Goswami. 2002. Using scanning electron microscopy to visualize photocatalytic mineralization of airborne microorganisms, in: Indoor Air 2002, 9th International Conference on Indoor Air Quality and Climate, Monterey, CA.

Gursumeeran Satsangi P., A. Kulshrestha, A. Taneja and P.S.P. Rao. 2011. Measurement of PM10 and PM2.5 aerosols in Agra, a semiarid region in India. Indian J. Radio Space 40: 203-210.

Hidaka H., Horikoshi S., Serpone N. and J. Knowland. 1997. In vitro photochemical damage to DNA, RNA and their bases by an inorganic sunscreen agent on exposure to UVA and UVB radiation. J. Photochem. Photobiol. A 111: 205-213.

Kikuchi Y., K. Sunada, T. Iyoda, K. Hashimoto and A. Fujishima. 1997. Photocatalytic bactericidal effect of $\mathrm{TiO}_{2}$ thin films: dynamic view of the active oxygen species responsible for the effect. J. Photochem. Photobiol. A 106(1-3): 51-56.

Limaye M.S. and W.T. Coakley. 1998. Clarification of small volume microbial suspensions in an ultrasonic standing wave. J. Appl. Microbiol. 84(6): 1035-1042.

Lu Z.X., L. Zhou, Z.L. Zhang, W.L. Shi, Z.X. Xie, H.Y. Xie, D.W. Pang and P. Shen. 2003. Cell damage induced by photocatalysis of $\mathrm{TiO}_{2}$ thin films. Langmuir 19: 8765-8768.

Malato S., P. Fernandez-Ibanez, M.I. Maldonado, J. Blanco and W. Gernjak. 2009. Decontamination and disinfection of water by solar photocatalysis: Recent overview and trends. Catal. Today 147: 1-59.

Matsunaga T., R. Tomoda, T. Nakajima and H. Wake. 1985. Photoelectrochemical sterilization of microbial cells by semiconductor powders, FEMS Microbiol. Lett. 29: 211-214.

Salata F., M. Fabiani, D. D'Alessandro, M. Cappelli D’Orazio. 2006. Effectiveness of UV Radiation for Reducing Aspergillus niger Contamination in Air-Conditioning Systems. Preliminary Results Abstracts, $6^{\text {th }}$ Intertantional Conference of the Hospital Infection Society, Amsterdam, The Netherlands.

Samson R.A., E.S. Hoekstra and J.C. Frisvad. 1996. Introduction to Foodborne Fungi. Baarn: Centraalbureau voor Schimmenuturees. Sanchez B., M. Sanchez-Munoz, M. Munoz-Vicente, G. Cobas, R. Portela, S. Suarez, A.E. Gonzalez, N. Rodriguez and R. Amils. 2012. Photocatalytic elimination of indoor air biological and chemical pollution in realistic conditions. Chemosphere 87: 625-630.

Sunada K., Y. Kikuchi, K. Hashimoto and A. Fujishima. 1998. Bactericidal and detoxification effects of $\mathrm{TiO}_{2}$ thin film photocatalyst. Environ. Sci. Technol. 32: 726-728.

Szponar B. 2010. Impurities in ventilation systems and air conditioning (in Polish). Magazyn Instalatora 140(4): 62.

Veremeichenko S.N. and G.M. Zdorovenko. 2004. Structure and Properties of the Lipopolysaccharide of Pseudomonas fluorescens IMV 2366 (Biovar III). Microbiology 73: 260-266.

Vohra A., D.Y. Goswami, D.A. Deshpande and S.S. Block. 2006. Enhanced photocatalytic disinfection of indoor air. Appl. Catal. B 65: 57-65.

Vonberg R.P., P. Gastmeier, B. Kenneweg, H. Holdack-Janssen, D. Sohr and I.F. Chaberny. 2010. The microbiological quality of air improves when using air conditioning systems in cars. BMC Infect. Dis. 10: 146 .

Vos P., G. Garrity, D. Jones, N.R. Krieg, W. Ludwig, F.A. Rainey K.H. Schleifer and W.B. Whitman (Eds.). 2009. Bergey's Manual of Systematic Bacteriology, Volume 3: The Firmicutes, Williams and Wilkins. 
